\title{
Facies and sedimentation of Coniacian deposits of the Kraków Swell in the Wielkanoc area (southern Poland)
}

\author{
Danuta OLSZEWSKA-NEJBERT ${ }^{1, *}$ and Ewa ŚWIERCZEWSKA-GŁADYSZ ${ }^{2}$ \\ 1 Faculty of Geology, University of Warsaw, wirki i Wigury 93, 02-089 Warszawa, Poland \\ 2 Institute of Earth Science, University of Lodz, Narutowicza 88, 90-139 Łódź, Poland
}

Olszewska-Nejbert D. and Świerczewska-Gładysz E. (2013) Facies and sedimentation of Coniacian deposits of the Kraków Swell in the Wielkanoc area (southern Poland). Geological Quarterly, 57 (1): 1-16, doi: 10.7306/gq.1062

\begin{abstract}
Coniacian deposits, ca. 1.5 m thick, cropping out in the Wielkanoc Quarry, north of Kraków in southern Poland, consist of firm, nodular and, less commonly, marly limestones with horizons of in situ, slightly phosphatized hexactinellid sponges and thick-shelled inoceramid bivalves. The succession is composed of foraminiferal-inoceramid packstones with common sand-sized quartz and glauconite grains at the base, passing upwards into foraminiferal or foraminiferal-inoceramid wackestones with or without rare glauconite. A microfacies analysis shows that planktonic foraminifers are the dominant forms, while benthic forms are rare. The facies indicates that sedimentation in the Wielkanoc area on the Kraków Swell, which separated the deeper Mid-Polish Trough Zone to the north-east and the Opole Trough Zone to the south-west, was generally calm (documented by abundant wackestones) and slow (indicated by the dominant sedimentary "coccolith system" and presence of glauconite) during the Coniacian. Rare episodes of non-deposition are recorded by episodes of phosphatization and minor intra-Coniacian discontinuity surfaces. The presence of hexactinellid sponges in the section studied are consistent with a calm environment, below the storm-wave base, with low rates of sedimentation. Subhercynian (latest Turonian-Coniacian Ilsede Phase) local tectonic movements had an important influence on the evolution of the region. They presumably led to subsidence of the Wielkanoc Block during the Early Coniacian. These movements were probably associated with activity on the Kraków-Myszków Fault Zone.
\end{abstract}

Key words: Upper Cretaceous, Coniacian, synsedimentary tectonics, Kraków Swell, microfacies, sponges.

\section{INTRODUCTION}

Stratigraphically well-documented Coniacian deposits are known from numerous outcrops in extra-Carpathian Poland: in the Sudetes and the Opole area (e.g., Tarkowski, 1991; Walaszczyk, 1992; Olszewska-Nejbert, 2007; Leszczyński, 2010), in the Nida Trough, and on the southwestern and northeastern margin of the Holy Cross Mountains (e.g., Walaszczyk, 1992; Walaszczyk and Wood, 1998; Walaszczyk et al., 2010). Extra-Carpathian Coniacian deposits have also been recognized in numerous boreholes (Jaskowiak-Schoeneichowa and Krassowska, 1988; Leszczyński, 2012). However, owing to poor palaeontological documentation, the stratigraphic Turonian-Coniacian and Coniacian-Santonian boundaries have only been approximated (Leszczyński, 2002). The Coniacian consists of marly-calcareous, calcareous, siliceous-calcareous, marly or siliceous-marly facies in most areas of Poland (Jaskowiak-Schoeneichowa and Krassowska, 1988; Walaszczyk, 1992; Leszczyński, 1997, 2012), similar to that in most of extra-Alpine Europe (Fig. 1).

\footnotetext{
* Corresponding author: don@uw.edu.pl
}

Received: March 8, 2012; accepted: July 21, 2012; first published online: December 6, 2012
The Upper Cretaceous deposits, especially the Turonian deposits of the Polish Jura Chain, have been studied by numerous scientists (e.g., Zaręczny, 1878; Sujkowski, 1926, 1934; Alexandrowicz, 1954; Marcinowski, 1974; Walaszczyk, 1992; Krajewski et al., 2000; Olszewska-Nejbert, 2005). Coniacian deposits, however, have been documented doubtfully. Zaręczny (1878) noted his Inoceramus Brogniarti (sic) near Giebultów (ca. $10 \mathrm{~km} \mathrm{NW}$ of Kraków). The taxon Cremnoceramus brongniarti is characteristic of Lower Coniacian deposits (e.g., Walaszczyk, 1992). Unfortunately, Zaręczny (1878) did not illustrate his Inoceramus Brogniarti and his description of these specimens corresponds more to the diagnosis of Inoceramus lamarcki, the index taxon of the uppermost Middle Turonian. Moreover, Zaręczny (1878) regarded his Inoceramus Brogniartias as synonym of I. lamarckii (sic). Smoleński (1906) noted the occurrence of Inoceramus haenleini, Inoceramus involutus and ?l. crassus in the Bonarka section (south of Kraków), which indicates a Coniacian age of this part of the deposits. However, that author also did not illustrate the species mentioned and their poor descriptions did not permit any verification by us. Moreover, Panow (1934) contested the presence of these species in the Bonarka section and showed that the Turonian deposits are overlain directly by marls with crinoid plates of Marsupites testudinarius - the index taxon of the uppermost Santonian. Sujkowski (1926) noted from the environs of Wolbrom sandy-glauconitic limestone with inoce- 


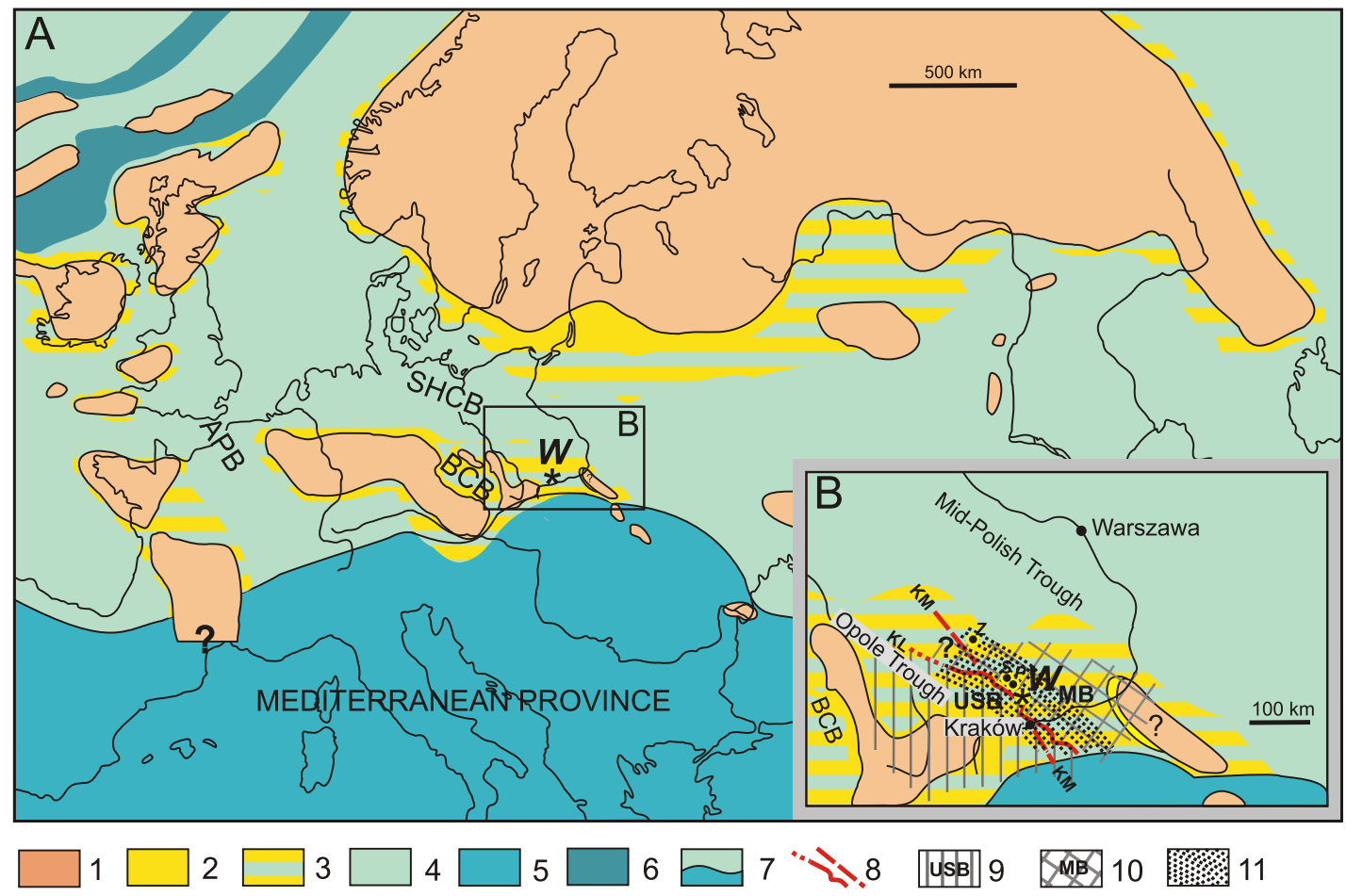

Fig. 1A - Turonian-Santonian palaeogeography with simplified distribution of facies in the North European Province (after Naidin, 1959; Kauffman, 1973; Ziegler, 1990; modified); B - inferred palaeogeography of Kraków Swell in Coniacian and Santonian times based on tectonic regional subdivision (according to aba, 1996; Buła et al., 2008) of the Upper Silesian Block and Małopolska Block below the sub-Permian and Mesozoic deposits

1 - land areas; 2 - deltaic, coastal and shallow-marine clastic facies (sands and conglomerates, sands and shales) 3 - shallow-marine facies (sands, marls, carbonate marls, marly carbonates, carbonates); 4 - mainly shallow-carbonate marine facies (marly carbonates, carbonates, chalk, white chalk, carbonate shales); 5 - approximate area of Mediterranean Province (without indication of facies); 6 - deeper marine shale facies (rift area); 7 - position of the future Alpine deformation front; W - Wielkanoc Quarry (southern Poland); APB - recent position of Anglo-Paris Basin; BCB - recent position of Bohemian Cretaceous Basin; SHCB - recent position of Subhercynian Cretaceous Basin; 8 - main tectonic zones distinguished in the basement (according to aba, 1996, 1999; Buła et al., 2008); 9 -inferred position of Upper Silesian Block (USB); 10 - inferred position of Małopolska Block (MB); 11 - inferred position of Kraków Swell during the Turonian, Coniacian and Santonian; KL - Kraków-Lubliniec Fault Zone, KM Kraków-Myszków Fault Zone, P - Przychody, S - Solca, W - Wielkanoc Quarry, Z - Zalesice

ramids and echinoids of Turonian to Santonian age. However, this dating was not confirmed by investigators in the following decades and numerous authors suggested a stratigraphic gap covering the latest Turonian through Middle Santonian in the southern segment of the Kraków Swell (e.g., Panow, 1934; Ró ycki, 1938; Alexandrowicz, 1954; Barczyk, 1956; Marcinowski, 1974). Walaszczyk (1992) found and illustrated the inoceramid index taxa for the Cremnoceramus crassus crassus/deformis deformis Zone (upper part of the Lower Coniacian) in loose blocks of sandy-glauconitic limestone near the northern wall of Wielkanoc Quarry. However, he did not study the succession directly at exposure and he pointed out that the location of the Coniacian deposits within the section is unclear. More recently, the inoceramid fauna revised by Walaszczyk (1992) from outcrops situated northwards from Wielkanoc showed the Coniacian age of deposits underlying the Santonian marls (Przychody, Solca), or Campanian siliceous chalk (Zalesice). Olszewska-Nejbert (2004) described a hardground at the Turonian/Coniacian boundary in the southern wall of Wielkanoc Quarry. Olszewska-Nejbert and Świerczewska-Gładysz (2009) and Świerczewska-Gładysz (2010) described the Coniacian/Santonian boundary in the northern wall of the quarry during a study of sponges from Upper Santonian deposits, but the Coniacian strata have not yet been investigated in detail.

The aim of this paper is, therefore, a reconstruction of the environment of Coniacian sedimentation on the Kraków Swell in the Wielkanoc area (Figs. 1 and 2), based on microfacies analysis, and a palaeontological and palaeoecological analysis of sponges from the deposits. Additionally, the petrographic and sedimentological data are integrated here with the geology and the tectonic development of the Kraków Swell area.

\section{GEOLOGICAL SETTING}

The Wielkanoc Quarry in the Polish Jura Chain exposes one of the most complete lower Upper Cretaceous successions in the area. The Turonian limestone sequence directly overlies Oxfordian (Upper Jurassic) massive limestones (e.g., Marcinowski, 1974; Marcinowski and Radwański, 1983). The Turonian deposits are assigned to the Inoceramus lamarcki-Inoceramus perplexus (= Inoceramus costellatus) zones (upper Middle-lower Upper Turonian) (Walaszczyk, 1992; with additional comments 


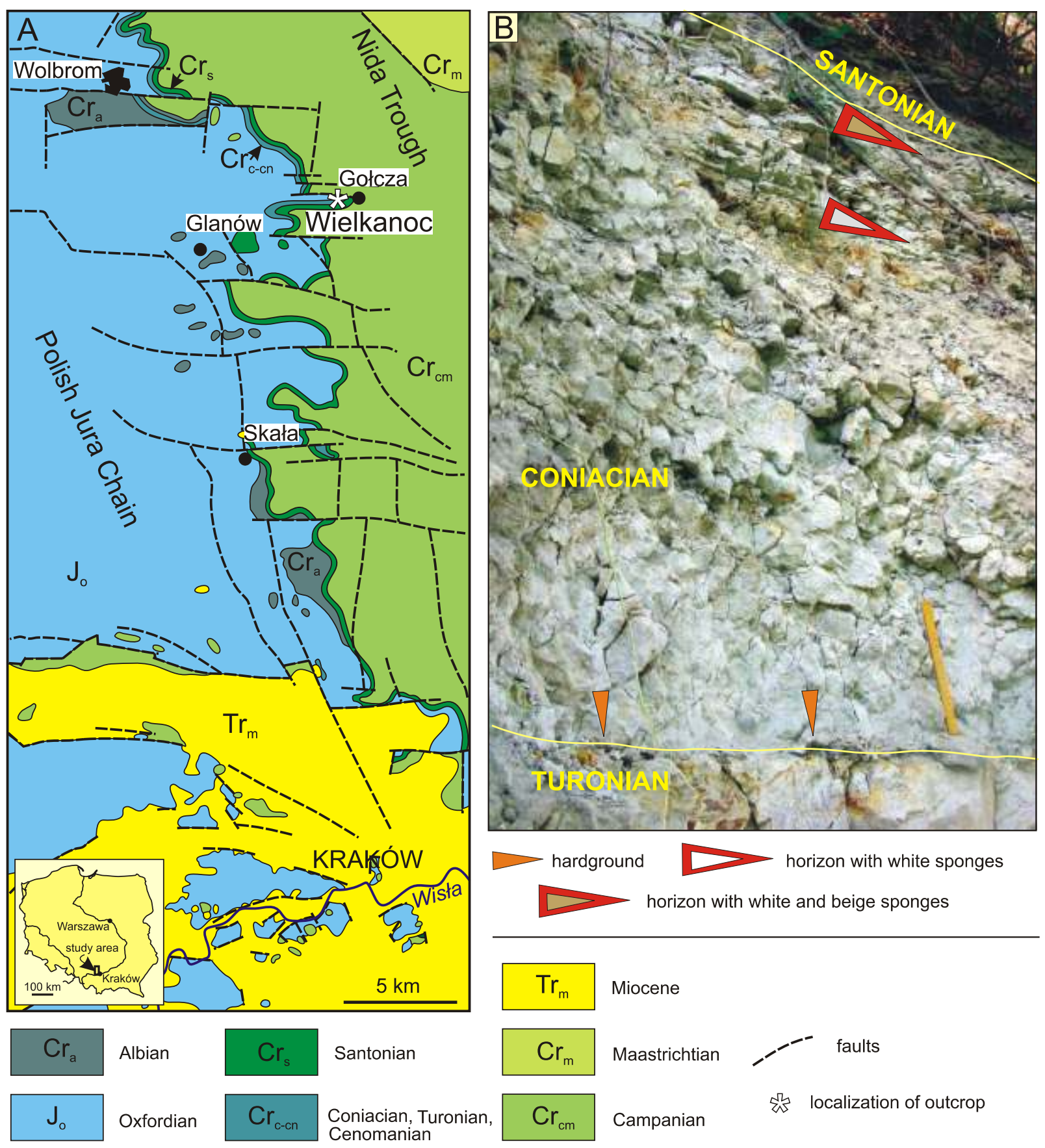

Fig. 2A - geological sketch-map of the Polish Jura Chain and Nida (Miechów) Trough with location of Wielkanoc Quarry (according to Kaziuk et al., 1978, simplified and modified); B - exposure of the Coniacian deposits in the northern wall of Wielkanoc Quarry (bar $20 \mathrm{~cm}$ )

about inoceramid zonation by Walaszczyk and Wood, 1998; Walaszczyk and Wood in Niebuhr et al., 1999) are exposed in the southern wall of the quarry. The $10 \mathrm{~m}$ thick Turonian succession is capped by a composite hardground with trace of phosphatization, $0.6 \mathrm{~m}$ thick Coniacian sandy-glauconitic limestone and Quaternary loess (Olszewska-Nejbert, 2004). That composite hardground was recognized also in the northern wall of quarry. The Coniacian deposits preserved here exceed $1.5 \mathrm{~m}$ in thickness and are covered by marly-glauconitic limestone of
Late Santonian age (Walaszczyk, 1992) with numerous redeposited phosphatized sponges at the base (Olszewska-Nejbert and Świerczewska-Gładysz, 2009).

The Turonian deposits occurring in other parts of the Polish Jura Chain, are more significantly reduced in thickness or/and strongly condensed than these in the Wielkanoc section (Zaręczny, 1878; Sujkowski, 1926, 1934; Alexandrowicz, 1954; Marcinowski, 1974; Walaszczyk, 1992; Jasionowski, 1995; Kudrewicz and Olszewska-Nejbert, 1997; Krajewski et al., 
2000; Olszewska-Nejbert, 2005; Kołodziej et al., 2010). In turn, Coniacian deposits are preserved only in a few places on the Kraków Swell (Walaszczyk, 1992; Kołodziej et al., 2010). After a long stratigraphic gap, Upper Santonian deposits covered a large area of the Kraków Swell (e.g., Alexandrowicz, 1969), while in some locations, Campanian deposits rest directly on Turonian or Coniacian limestones (Walaszczyk, 1992; Zapałowicz-Bilan et al., 2009; Kołodziej et al., 2010).

The elongation of the Polish Jura Chain, in a NW-SE/NNW-SSE direction, is consistent with the extension of the Kraków-Myszków Tectonic Zone that separates the Małopolska Block from the Upper Silesia Block in the study area (Fig. 1). This zone is a part of the major Kraków-Lubliniec Fault Zone ( aba, 1999; Buła et al., 2008) and also constitutes a southeastern fragment of the Kraków-Szczecin Tectonic Zone ( aba, 1996). Strike-slip tectonic activity along the Kraków-Myszków Tectonic Zone during the Paleozoic was responsible for the origin of a saturated net of faults (Buła, 1994;

aba, 1999). This zone was rejuvenated in subsequent periods, e.g., in the Triassic ( aba, 1999), Jurassic (Matyszkiewicz et al., 2006) and Cenozoic (Jurewicz et al., 2007). On January 6,2012 , a series of brief seismic earthquakes was noted in erków (near Kalisz), in the Kraków-Szczecin Tectonic Zone (http://www.pgi.gov.pl/pl/archiwum-aktualnosci-instytutu/4032trzesienie-ziemi-w-zerko-wie). This means that this tectonic zone remains active.

Palaeogeographically, the study area was situated in the Holy Cross Unit segment of the Mid-Polish Trough during the Coniacian (Dadlez, 1997; Hakenberg and Świdrowska, 1998; Świdrowska and Hakenberg, 1999). The present Polish Jura was a positive element as a submarine swell (the Kraków Swell) in the Cenomanian through to the Santonian and its southern unit (segment) was uplifted to a high level (Marcinowski, 1974). The swell separated the Holy Cross segment of the Mid-Polish (Danish-Polish) Trough and the Opole Trough (Marcinowski, 1974; Walaszczyk, 1992; Olszewska-Nejbert, 2004). Subhercynian movements during the Turonian were responsible for the breakdown or activation of pre-existing blocks (Marcinowski, 1974). Synsedimentary block movements (Marcinowski, 1974; Walaszczyk, 1992; Olszewska-Nejbert, 2004; Marcinowski and Radwański, 2009; Kołodziej et al., 2010) caused development of the many stratigraphic gaps and discontinuity surfaces (abrasive surfaces, omission surfaces, hardgrounds), which are observed in many regions of the Kraków Swell. One of such places was the present Wielkanoc area, called here the Wielkanoc Block.

\section{MATERIAL AND METHODS OF STUDY}

During the fieldwork, a detailed lithological section of the Coniacian was measured and sampled for thin sections. Sampling was carried out in the lithostratigraphic units recognized (see Fig. 3). Fossils were collected bed-by-bed and labelled. The material infilling the spongocoel and interspicular space of the collected sponges was examined. Petrographic investigations were carried out at the Scanning Electron Microscope and Microanalysis Laboratory of the University of Warsaw, using a Nikon ECLIPSE E600W POL optical microscope and a JEOL JSM-6380LA scanning electron microscope.

\section{LITHOLOGY, MICROFACIES AND STRATIGRAPHY}

The Coniacian deposits crop out at the northern wall of the Wielkanoc Quarry. The deposits directly overlie a hardground developed on the Upper Turonian pelitic limestone (foraminiferal-calcisphere wackestone, locally transitional to wackestone/packstone texture; see Fig. 4A; cf. Olszewska-Nejbert, 2004). The $10 \mathrm{~m}$ thick Turonian deposit in Wielkanoc represents the undivided upper Middle (Inoceramus lamarcki Zone) and lower Upper Turonian (Inoceramus costellatus Zone = Inoceramus perplexus Zone) (according to Walaszczyk, 1992; and supplementary data by Walaszczyk and Wood, 1998; Walaszczyk and Wood in Niebuhr et al., 1999). The Upper Santonian deposits (Walaszczyk, 1992), rich in redeposited phosphatized sponges at its base, overlie the Coniacian deposits (Olszewska-Nejbert and Świerczewska-Gładysz, 2009). The Coniacian deposits exceed ca. $1.5 \mathrm{~m}$ in thickness and were divided into six units (a-f) as follows from the base to the top (Fig. 3):

$\mathrm{a}-0.2 \mathrm{~m}$ thick, fairly solid sandy-glauconitic limestone (cf. Olszewska-Nejbert, 2004) with a large admixture of quartz at the base is represented by a foraminiferal-inoceramid packstone with a large admixture of quartz (ca. $20 \%$ ) and glauconite (ca. 10\%) (Fig. 4B, C). This facies also represents the sandyglauconitic infill of the burrows and borings of the Turonian hardground. The content of sand-sized quartz and glauconite decreases towards the top of the unit.

b $-0.65 \mathrm{~m}$ thick, nodular limestone with rare quartz (ca. $5 \%$ ) and glauconite (ca. 5\%), mainly in the lower part of the unit (Fig. 4D), represented by foraminiferal wackestone, transitional to wackestone/packstone texture, with rare calcareous dinoflagellate cysts (c-dinocysts), large fragments of inoceramids and fine fragments of echinoderm. The upper part of the unit has little or no glauconite $(<2 \%)$ and quartz $(<2 \%)$; well-preserved planktonic foraminifers predominate (Fig. 4E, F). Planispiral and trochospiral forms with globular chambers are numerous, while small serial planktonic foraminifers are very rare. Keeled forms also occur. Coccoliths are the dominant component of the calcareous matrix, as in the following units.

$c-0.15 \mathrm{~m}$ thick, glauconite-bearing, solid limestone is strongly ferruginous. It is a foraminiferal wackestone, transitional to wackestone/packstone texture, with c-dinocysts, inoceramid debris and fragments of echinoids (Fig. 5A). The microfacies is similar to the microfacies of unit b. In the upper part of the unit, an intra-Coniacian discontinuity surface occurs in the foraminiferal wackestone, which is covered by phosphatized microstromatolites (Fig. 5B). The amount of glauconite varies between $<1$ and ca. $10 \%$, especially close to phosphatized zones. In unit c, rare weakly phosphatized sponges (Fig. 3) from the orders Hexactinosida and Lychniscosida and thick-walled inoceramid bivalves and inoceramid debris, as well as irregular echinoids (Micraster and Echinocorys), occur. Weakly visible burrows penetrating as far as $8 \mathrm{~cm}$ down occur at the top of the unit.

$d-0.25 \mathrm{~m}$ thick, solid limestone, with a low glauconite content (ca. 1-2\%), is represented by a foraminiferal/foraminiferalinoceramid wackestone, transitional to wackestone/packstone texture, with rare c-dinocysts and fragments of echinoids (Fig. 5C). Planktonic foraminifers (mainly planispiral and trochospiral forms with globular chambers) dominate, but are not so wellpreserved as in units $b-c$; they are locally broken. The content 
of inoceramid debris increases locally, resulting in the formation of foraminiferal-inoceramid packstone.

e $-0.12 \mathrm{~m}$ thick, marly limestone, with a low glauconite content (ca. $1-2 \%$ ), is represented by a foraminiferal-inoceramid/foraminiferal wackestone, transitional to wackestone/packstone texture, with rare c-dinocysts and fragments of echino-

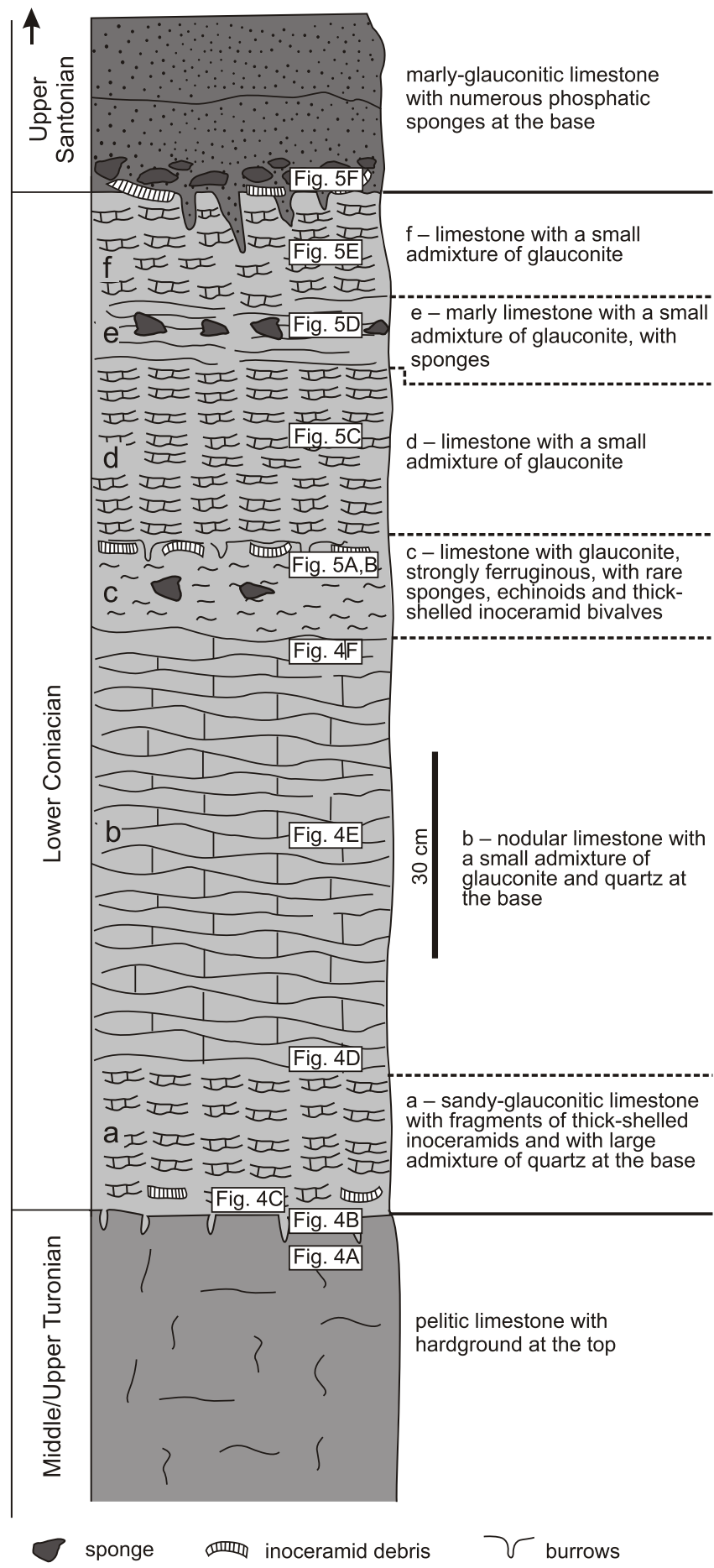

Fig. 3. Geological log of Coniacian deposits in the northern wall of Wielkanoc Quarry (stratigraphy after Walaszczyk, 1992, with additional comments by Walaszczyk, 2000; Walaszczyk and Wood, 1998, Walaszczyk, Wood in Niebuhr et al., 1999) ids (Fig. 5D). Planktonic foraminifers, similar to those in unit d, dominate. Small phosphatized clasts of foraminiferal wackestone and burrows occur. Weakly phosphatized sponges from the order Hexactinosida and Lychniscosida (Figs. 6 and 7) occur commonly in one horizon in this unit (Fig. 3). Coccoliths are the dominant component of the calcareous matrix and also infill the spongocoel of the sponges (Fig. 7D).

$f-0.15 \mathrm{~m}$ thick solid limestone with rare glauconite (ca. $2-5 \%$ ) is represented by a foraminiferal wackestone with rare c-dinocysts and fragments of echinoids (Fig. 5E). Planktonic foraminifers are dominant and are better preserved than in units $\mathrm{d}$ and e. Planispiral and trochospiral forms with globular chambers are numerous but also keeled forms are present while small serial planktonic foraminifers are exremely rare. Burrows penetrating as far as ca. $10 \mathrm{~cm}$ down occur at the top of unit.

The Upper Santonian deposits overlie the Coniacian strata erosionally. They consist of marly-glauconitic limestones in the lower part (the amount of glauconite exceeds 15\%) and are represented by an inoceramid packstone (Fig. 5F). Numerous phosphatized sponges and intraclasts of phosphatized foraminiferal wackestone are present here (Olszewska-Nejbert and Świerczewska-Gładysz, 2009).

In the deposits studied, Walaszczyk (1992) described the following inoceramids: Cremnoceramus crassus (Petrascheck), C. ernsti (Heinz), C. cf. deformis (Meek), Inoceramus cf. madagascariensis Heinz, I. lusatiae Andert. This dates the interval as the upper Lower Coniacian Cremnoceramus crassus crassus/deformis deformis Zone according to the zonation of Walaszczyk and Wood (1998, 1999). The appearance of the echinoids Micraster cortestudinarium (Goldfuss) and Echinocorys ex gr. scutata Leske supports this age.

\section{SPONGES IN THE CONIACIAN SECTION}

Sponges in the Coniacian deposits occur at two horizons, one horizon in unit $\mathrm{c}$ and the second in unit e (Fig. 3). They are less abundant than in the redeposited or lag deposits at the base of the Santonian (Olszewska-Nejbert and ŚwierczewskaGładysz, 2009).

All sponges represent the class Hexactinellida and are characterized by a rigid siliceous skeleton, composed of hexactin spicules. The siliceous skeletons of all specimens are completely dissolved and voids only after spicules are preserved (Figs. 6A, D, E and 7A). The empty voids after dissolved spicules are in places filled with calcite. Among the collection studied, two species of the order Hexactinosida have been recognised: Periphragella plicata Schrammen, 1902 and Polyopesia angustata Schrammen, 1902, as well as six species of the order Lychniscosida: Plocoscyphia communis Moret, 1926; Etheridgia mirabilis Tate, 1864; Leiostracosia angustata (Roemer, 1841); Rhizopoterion cribrosum (Phillips, 1829); Sporadoscinia venosa Schrammen, 1912 and Astropegma stellata (Roemer, 1841).

Two groups of sponges were distinguished macroscopically in the collection: white and beige sponges. All sponges are slightly phosphatized (Fig. 7); the white sponges are only weakly phosphatized while the beige ones underwent stronger phosphatization (Olszewska-Nejbert and ŚwierczewskaGładysz, 2009). Both, sponge wall and infilling of the spongocoel are usually phosphatizated. It is also possible that only the sponge wall has been slightly phosphatized (Fig. 7A-C), whereas the spongocoel was infilled by calcareous sediment, 

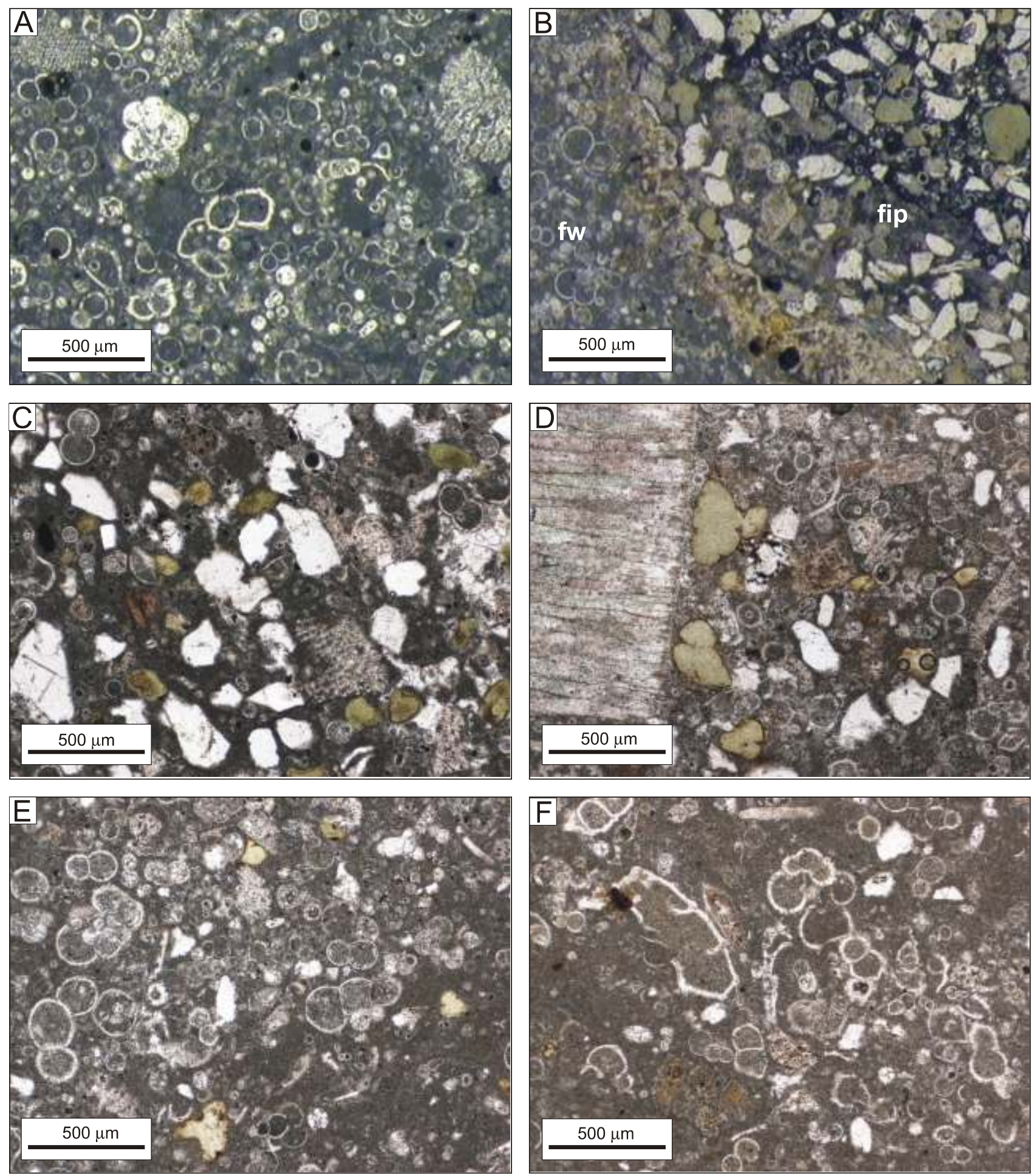

Fig. 4. Microfacies of topmost part of Turonian and upper part of Lower Coniacian deposits at Wielkanoc

A - foraminiferal-calcisphere wackestone, transitional to wackestone/packstone texture, Turonian just below the hardground; B hardground boundary between the foraminiferal-calcisphere wackestone ( $\mathrm{fw}$ ) of Turonian and foraminiferal-inoceramid packstone with a large admixture of quartz and glauconite (fip) at the base of the Lower Coniacian; $\mathbf{C}$ - foraminiferal-inoceramid packstone with admixture of quartz and glauconite, base of unit a; $\mathbf{D}$ - foraminiferal-inoceramid packstone with admixture of quartz and glauconite, boundary between the top of unit $a$ and base of unit $b ; \mathbf{E}$ - foraminiferal wackestone with dominant planktonic foraminifers, transitional to wackestone/packstone texture, middle part of unit b; $\mathbf{F}$ - foraminiferal wackestone, transitional to packstone with dominant planktonic foraminifers, upper part of unit $b$; sample sites see Figure 3 

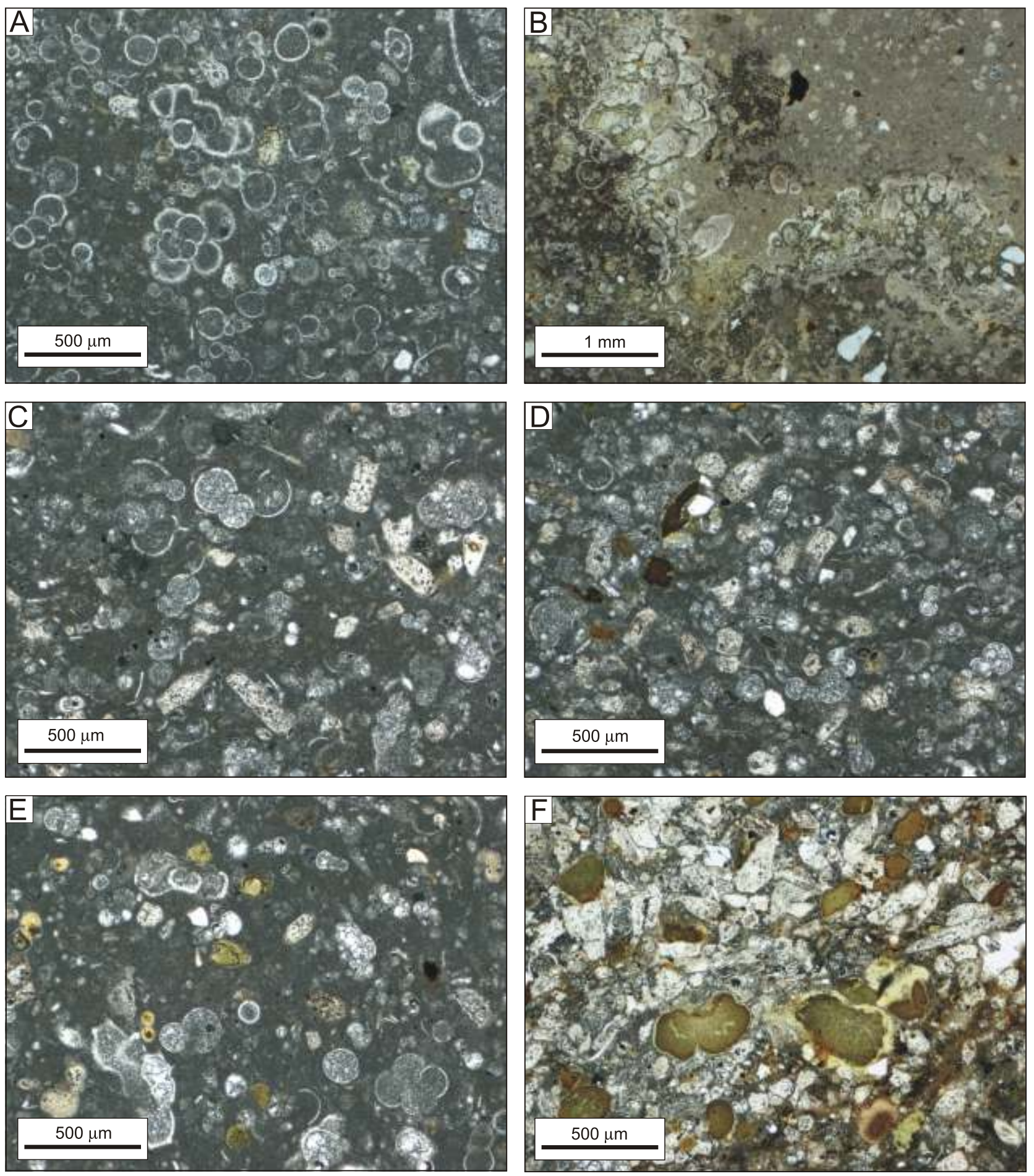

Fig. 5. Microfacies of upper part of Lower Coniacian and base of Santonian deposits at Wielkanoc

A - foraminiferal wackestone, transitional to wackestone/packstone texture, dominant planktonic foraminifers (unit c); B - intraConiacian discontinuity surface in the foraminiferal wackestone covered by phosphatized microstromatolite (unit c); $\mathbf{C}-$ foraminiferal/foraminiferal-inoceramid wackestone, transitional to wackestone/packstone texture (unit d); $\mathbf{D}$ - foraminiferal-inoceramid/foraminiferal wackestone, transitional to wackestone/packstone texture, unit e; $\mathbf{E}$ - foraminiferal wackestone with rare glauconite, unit f; $\mathbf{F}$ inoceramid packstone with frequent glauconite, base of Upper Santonian; sample sites see Figure 3

without traces of phosphatization (Fig. 7D, E). Epibionts with a calcareous, non-phosphatized skeleton, such as oysters, are attached to some sponges (Fig. 6F).

The sponges are poorly cemented, rather soft, not resistant to destruction due to the lack of siliceous skeletons and the weak phosphatization. Therefore, the outer surfaces of the sponges are poorly preserved (Fig. 6). The specimens broke easily during extraction from the rock. In contrast to the crushed and rounded dark sponges from the base of the Santonian (OlszewskaNejbert and Świerczewska-Gładysz, 2009), the Coniacian sponges have not been mechanically destroyed. 


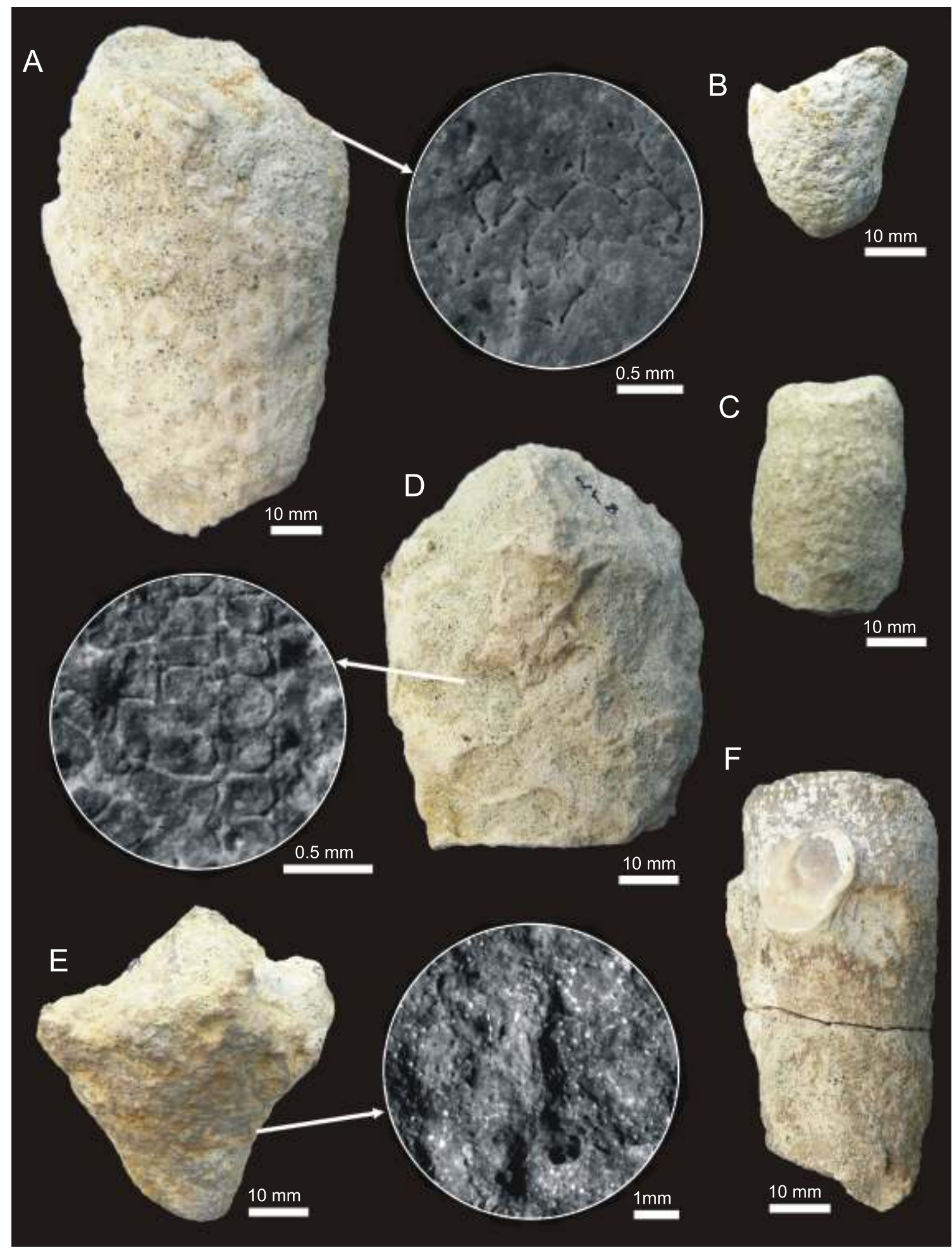

Fig. 6. Hexactinosid and lychniscosid sponges from the Coniacian deposits

A-D - white sponges: A- Rhizopoterion cribrosum (Phillips, 1829), lateral view and voids after dictyonal skeleton visible in transverse section of the wall; B - Sporadoscinia venosa Schrammen, 1912, lateral view; C - Astropegma stellata (Roemer, 1841), lateral view; D - Plocoscyphia communis (Moret, 1926), lateral view and voids after dictyonal skeleton on dermal surface; E, F - beige sponges; E - Polyopesia angustata Schrammen, 1902, lateral view and fragment of dermal surface with canal openings and voids after dictyonal skeleton; F - Leiostracosia angustata (Roemer, 1841), lateral view 

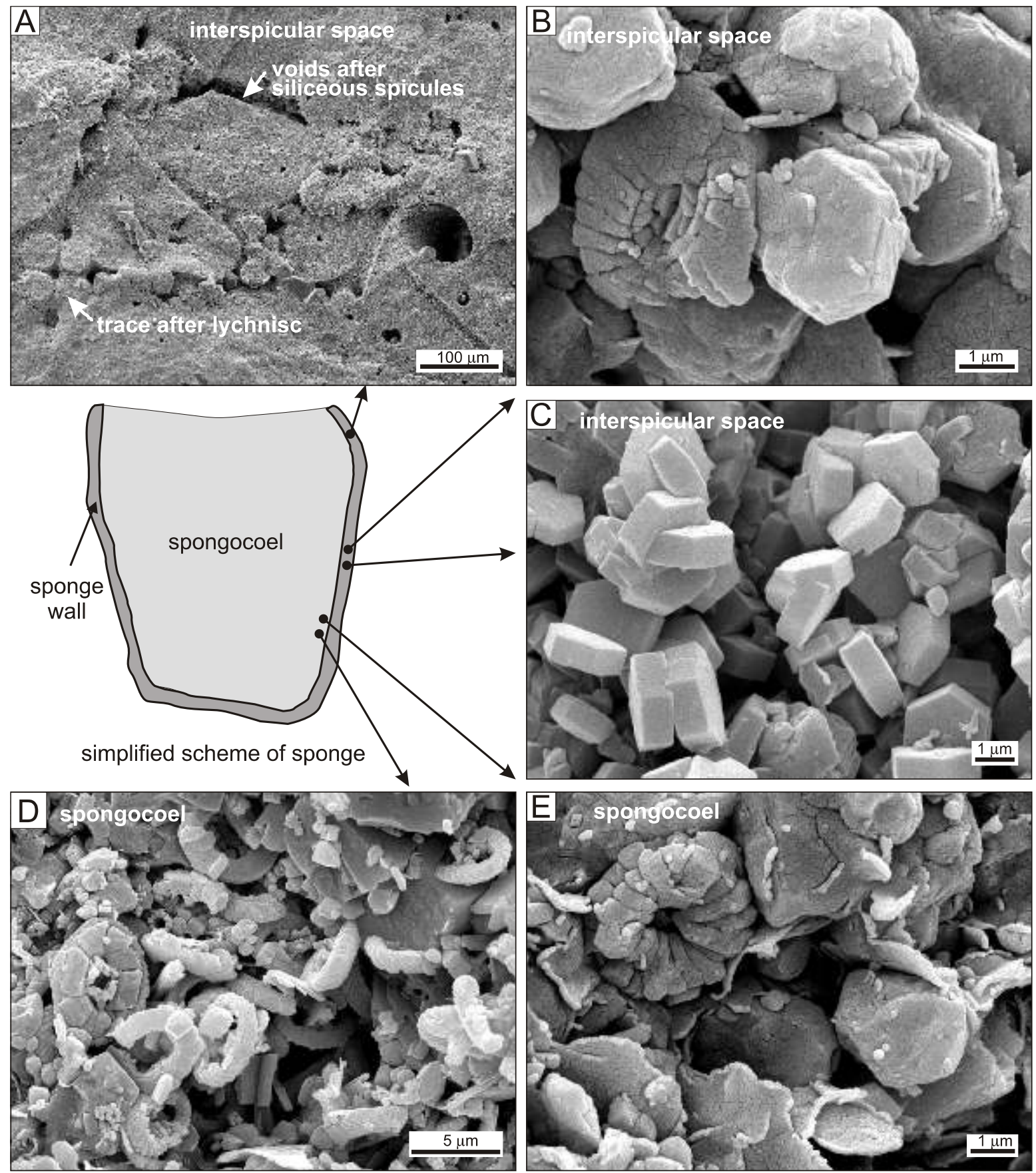

Fig. 7. SEM images showing petrography of the infillings of the spongocoel and interspicular spaces of the lychniscosid sponge wall

A - wall of lychniscosid sponge with empty voids after dictyonal skeleton and slightly phosphatized material infilling interspicular spaces; some voids are filled by late calcite; $\mathbf{B}$ - interspicular spaces infilled by weakly phosphatized coccolith micrite and aggregates of euhedral francolite; $\mathbf{C}$-aggregates of euhedral francolite; $\mathbf{D}$-calcareous coccolith micrite in spongocoel; $\mathbf{E}$-calcareous coccolith micrite with clay minerals in spongocoel

\section{REMARKS ABOUT THE ECOLOGY AND PALAEOCOLOGY OF SPONGES}

The hexactinosids and lychniscosids in the Coniacian deposits of Wielkanoc belong to the class Hexactinellida, commonly called the glass sponges. There are ca. 500 recent species of Hexactinellida and all are restricted to the marine environment (Reiswig, 2002). The constitution of the sponges and their vital functions are adapted to deep sea environments where slow sedimentation dominates, and there are low energy, cold water and oligotrophic conditions (Tabachnick, 1991; Krautter, 1997). Therefore, most hexactinellids live in the bathyal zone, although some of them occur also in the abyssal zone, which is a rare phenomenon among the benthic fauna (e.g., Janussen and Tendal, 2007). For example, sponges of the genus Periphragella live at a depth of 256-1919 m (Reiswig and Wheeler, 2002).

A few hexactinellids, among which representatives of the Hexactinosida and Lychniscosida, are extremely rare, occur in 
the deeper zone of the shelf, below 100-120 m (van Soest and van Stentoft, 1988; Finks and Rigby, 2004). The only known contemporary sponge reef is located at a depth of about 120-240 m in British Columbia (e.g., Leys et al., 2004). The development of that reef at such relatively shallow depths is associated with the circulation of sea currents, such that the conditions in the shelf zone are similar to an oceanic environment (Leys et al., 2004; Whitney et al., 2005). The sponge assemblage of the modern sponge reef is taxonomically very poor, consisting of only three species of Hexactinosida. Several other species of Hexactinosida and Lychniscosida have been found at depths of 82-113 $\mathrm{m}$ in the Indonesia seas (Ijima, 1927). The single species Aphrocallistes vastus appears in the fjords of British Columbia (Leys et al., 2004). The representatives of that species are usually concentrated in the deeper parts of the fjords but a few specimens have been noted at a depth of 20-30 m. The presence of hexactinellids in the fjords, as in the case of the reef zone, is associated with specific environmental conditions, including low water temperature and limited light. Nowadays, the fjords of British Columbia are the only place with a well-documented occurrence of hexactinosids at shallow depths. There is also no record of recent lychniscosids living in water shallower than 80 m (Finks and Rigby, 2004). Shallow marine environments are inhabited by sponges from the class Demospongea, among which forms without a rigid skeleton predominate (Finks and Rigby, 2004).

Due to the preference of glassy sponges for deep water, their intensive development coincided with periods in Earth history when global sea level was particularly high (Pisera, 1999). The last great bloom of hexactinellids took place during the Late Cretaceous; later, many hexactinellids gradually became extinct (Pisera, 1999). Of the eight genera recognized in the Coniacian succession, only one genus (Periphragella) is represented in the modern fauna (Reiswig and Wheeler, 2002).

All species of sponges recognized in the Coniacian deposits of Wielkanoc are known from the epicontinental Upper Cretaceous deposits of Europe (e.g., Świerczewska-Gladysz, 2006; Olszewska-Nejbert and Świerczewska-Gładysz, 2009). The maximum depth of the Late Cretaceous seas in Europe is estimated to have been at least $100 \mathrm{~m}$, based on the presence of sponge assemblages containing Hexactinosida and Lychniscosida (e.g., Defretin-Lefranc, 1960; Nestler, 1961; Wagner, 1963; Reid, 1968; Świerczewska-Gładysz, 2006; Schneider et al., 2011). The Lithistida (an informal polyphyletic group of Demospongea) and calcareous sponges, known from Upper Cretaceous shallow-water deposits (e.g., Defretin-Lefranc, 1960; Ulbrich, 1974), have not been recognized in the succession studied.

Modern hexactinellids mainly inhabit hard substrates (e.g., Krautter et al., 2006; Hogg et al., 2010), whilst numerous Late Cretaceous species had well-evolved rhizoids (long processes) which stabilized them on the soft bottom (e.g., ŚwierczewskaGładysz, 2006; Olszewska-Nejbert and Świerczewska-Gladysz, 2011). The assemblage investigated consists of rhizoidal forms adapted to live on soft bottoms (cf. Reid, 1962). Only one species (Plocoscyphia communis) had a basal plate attached to hard elements. These hard elements may be bioclasts resting on the muddy (soft) bottom, including the skeletons of other dead sponges. Other epibionts occur also on the fossil sponges, because in the environment of slow sedimentation preferred by the sponges (e.g., Krautter, 1997), their skeletons remained exposed on the bottom for a longer time (Mehl and Niebuhr, 1995; Žitt et al., 2006).

\section{DISCUSSION}

After a significant episode of global sea level drop during the early Late Turonian, global sea level rose in the latest Turonian and was relatively stable during the entire Coniacian stage; however, small amplitude fluctuations in sea level are marked (Haq et al., 1988). A significant sea level drop was again noted in the Late Santonian (Haq et al., 1988).

The initiation of the formation of the latest Turonian-Early Coniacian (post-Inoceramus perplexus Zone, pre-Cermnoceramus crassus crassus/deformis deformis Zone) composite hardground in the Wielkanoc area (Olszewska-Nejbert, 2004; Olszewska-Nejbert and Świerczewska-Gładysz, 2009) corresponds well to the Late Turonian sea level drop (e.g., Hancock and Kauffman, 1979; Haq et al., 1988; Hancock, 1990). Initiation of formation of this hardground corresponds quite well with a major mid-Late Turonian unconformity described as Sequence Boundary Tu 4 at the base of the Seugast Member Roding Formation in the Bodenwöhrer Senke (NE Bavaria), close to the southwestern margin of the Bohemian Massif (Niebuhr et al., 2011) and at the erosional base of the Soest Greensand Member of the Salder Formation recognized in the Werl borehole in the southern Münsterland Cretaceous Basin (Richardt and Wilmsen, 2012). The unconformity Tu 4 in Germany was connected with eustatic shallowing of the sea (Niebuhr et al., 2011; Richardt and Wilmsen, 2012). However, at these places in Germany above the unconformity surface Late Turonian sedimentation continued. In some places on the Kraków Swell, carbonate sedimentation resumed in the late Early Coniacian, especially on subsiding blocks such as the Wielkanoc Block (Olszewska-Nejbert, 2004; OlszewskaNejbert and Świerczewska-Gładysz, 2009). The Coniacian deposits at Wielkanoc include a relatively large admixture of glauconite and detrital quartz at their base, but in the matrix coccolith plates clearly prevail over c-dinocysts. The detrital quartz quickly disappears and planktonic foraminifera and coccoliths became the main components of the deposits. The prevalence amount of coccoliths suggests generally oligotrophic conditions of the sea, with the sedimentation area far away from the source of nutrients, meaning that it was far from land on the one side, and from the upwelling zone from of the open sea on the other. Such a style of sedimentation, known as the "blue water" coccolith system, was described from the Cenomanian deposits of Germany (Wilmsen, 2003). The sedimentation in the Wielkanoc area represents the more distal position, situated far away from any emergent massifs, because proximity of any land area should lead to development the "green water" c-dinocysts system (cf. Wilmsen, 2003; Wiese et al., 2004)

The presence of sponges of the orders Lychniscosida and Hexactinosida indicates a calm environment below storm-wave base (cf. Schneider et al., 2011). Similar conditions in that area are indicated by the dominant foraminiferal wackestone microfacies and the abundance of planktonic foraminifers. Among them, planispiral and trochospiral forms with globular chambers prevail. These forms are regarded as deeper-dwellers than the small serial foraminifers (Leckie, 1987; Dubicka and Peryt, 2012a, b with references), which are very rare in the succession studied. Keeled forms, regarded to be the deepest-dwelling foraminifers (Dubicka and Peryt, 2012a, b with references), are also present, but they are not so common. More common inoceramid debris occurs only at the base of unit a, at the top of unit $c$ and at the base of unit $d$. It may indicate that 
these deposits were formed near storm wave base, but surely below fair-weather wave base (cf. Wiese, 2009).

Slow sedimentation, and even episodic breaks in sedimentation, are indicated by: the occurrence of sponges the presence of epibionts on the sponges; the presence of glauconite; the weak episodes of phosphatiztion, and the presence of intra-Coniacian discontinuity surfaces. Additionally, the dominant coccolith sedimentary system recognized in the Coniacian succession is regarded as one of low $\mathrm{CaCO}_{3}$ accumulation rates (Wilmsen, 2003; Wiese et al., 2004).

Deposits of late Early Coniacian age in the Polish Jura Chain known from outcrops located NW of Wielkanoc (Fig. 1B), are reduced in thickness: ca. $0.8 \mathrm{~m}$ at Przychody (ca. $20 \mathrm{~km}$ ), $0.5 \mathrm{~m}$ at Solca (ca. $30 \mathrm{~km}$ ) and ca. $0.3 \mathrm{~m}$ at Zalesice (ca. $60 \mathrm{~km}$ ) (Walaszczyk, 1992). In a neighbouring area (Fig. 8), in the Opole region, ca. $140 \mathrm{~km}$ west of Wielkanoc, Coniacian deposits are

A
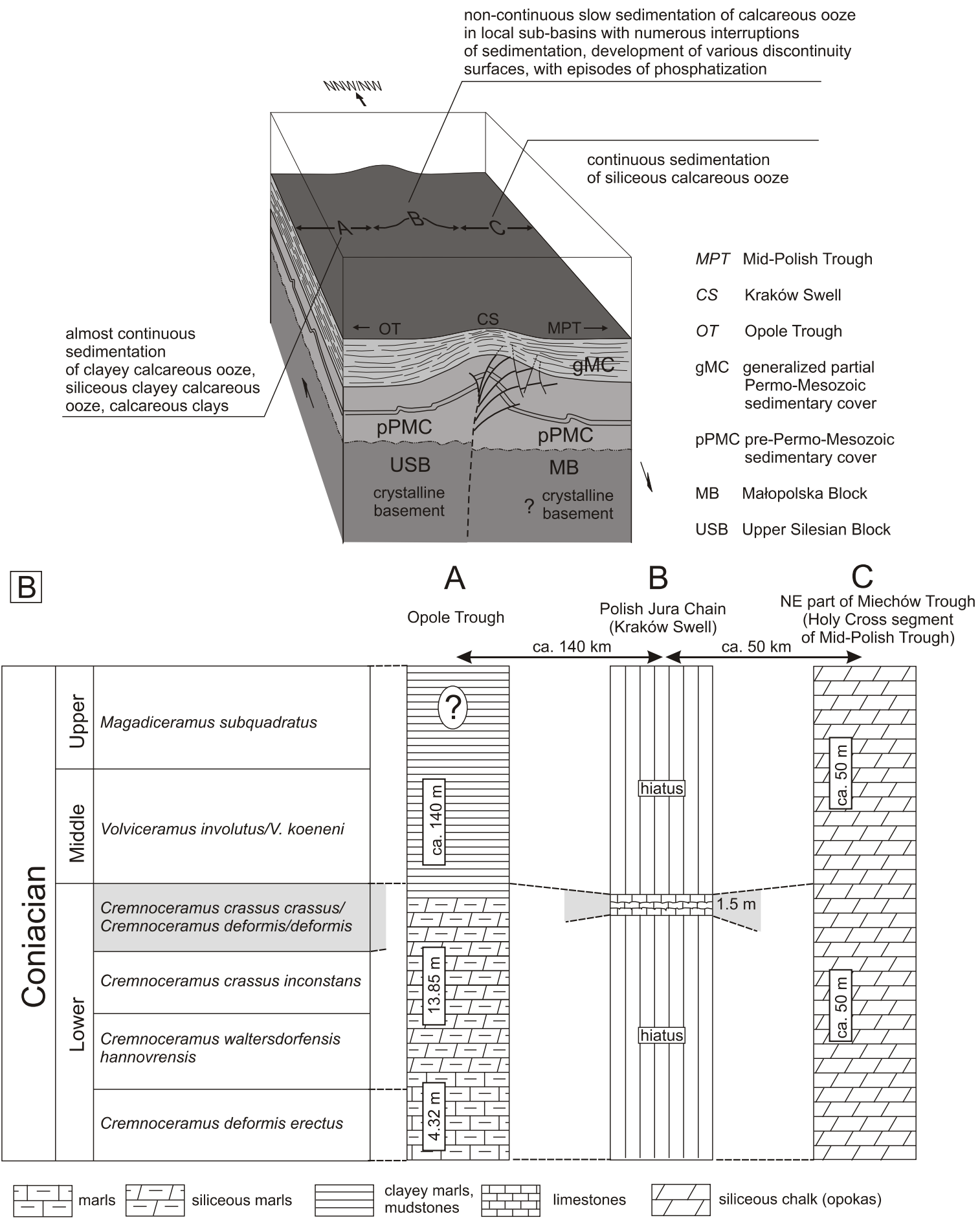

Fig. 8A - cartoon showing a simplified model of the Kraków Swell during the Coniacian with different kinds of sedimentation on the Kraków Swell and adjacent areas; the model does not include numerous local faults transverse to the main strike-slip direction and does not include local sub-basins on the Kraków Swell; B - simplified Coniacian chronostratigraphic scheme of facies distribution in the Opole Trough (after Walaszczyk, 1992; Olszewska-Nejbert, 2007) through the Wielkanoc (Polish Jura Chain) to the NE outskirts of the Miechów Trough (after Walaszczyk, 1992) 
represented by an almost complete Coniacian succession, over 150 m thick (Radwańska, 1969; Walaszczyk, 1992). Similarly, in a north-easterly direction, towards the Miechów Trough, close to the margin of the Holy Cross Mountains, Coniacian deposits thicken again, exceeding ca. 100 m (Fig. 8; Walaszczyk, 1992). We suggest that the reduced thickness of Coniacian deposits on the Wielkanoc Block may result from at least three factors. The first factor is the lack of sedimentation during the development of the hardground near the Turonian-Coniacian boundary (Olszewska-Nejbert, 2004). The second is a low rate of sedimentation connected with the dominant sedimentary coccolith system (cf. Wilmsen, 2003) during the late Early Coniacian. The third factor is the erosion of an unknown thickness of strata during the late Early Coniacian to Late Santonian interval (Olszewska-Nejbert and Świerczewska-Gładysz, 2009).

The hiatus, representing the latest Turonian and earliest Coniacian development of the composite hardground (Fig. 8), was connected with the uplift of the Kraków Swell (Walaszczyk, 1992; Olszewska-Nejbert, 2004; Olszewska-Nejbert and Świerczewska-Gładysz, 2009). That phenomenon corresponds well with the early Ilsede tectonic pulse (Olszewska-Nejbert, 2004), for which there is evidence in the Anglo-Paris Basin and in northern Germany (Mortimore and Pomerol, 1997; Mortimore et al., 1998; Mortimore, 2011). The second hiatus (see Fig. 8) in the interval Middle Coniacian through Middle Santonian in the Wielkanoc area corresponds well with the Main Ilsede tectonic pulse as recorded in the Anglo-Paris Basin and in northern Germany, where in several sections the hiati enclose the entire, or a significant part of, the Coniacian (Wood et al., 1984; Mortimore and Pomerol, 1997; Niebuhr and Prokoph, 1997; Mortimore et al., 1998; Voigt et al., 2004, 2006).

The tectonic activity in the Kraków-Myszków Zone (where the Wielkanoc Block was situated), reflected on the Kraków Swell in the Turonian, Coniacian and Santonian, was recognized as a result of Subhercynian movements (Marcinowski, 1974; Walaszczyk, 1992; Olszewska-Nejbert, 2004; Olszewska-Nejbert and Świerczewska-Gładysz, 2009), leading to the development of local deeper sub-basins within the generally uplifted Kraków Swell (Fig. 8). Coniacian deposits are very scarce on the Polish Jura Chain, and these deposits have been preserved probably only on the subsiding blocks. The Wielkanoc Block was probably the best example of such a place, where a thin succession of Coniacian deposits (upper Lower Coniacian Cremnoceramus crassus crassus/deformis deformis Zone or part of this zone) was preserved.

Similar tectonic phenomena are described from northern Germany and the Anglo-Paris Basin, where strike-slip tectonism along major basement zones controlled sedimentation in the latest Turonian and Coniacian (Ilsede Phase) and led to the formation of numerous angular discordances, sedimentary hiati, facies changes, slumps, submarine slides, turbidites, hardgrounds and other discontinuity surfaces (Mortimore et al., 1998; Mortimore, 2011). Tröger (1995) showed that in the relatively large Subhercynian Cretaceous Basin, sedimentation was controlled by tectonic activity in the Paleozoic basement. A similar phenomenon was described by Uličný et al. (2003) in the Bohemian Cretaceous Basin. Mortimore et al. (1998) proposed that the Sub- hercynian strike-slip tectonism along the lineaments in the Variscan basement of northern Germany and the Anglo-Paris basins, during the latest Turonian-Coniacian, controlled sedimentation to a larger degree then did the eustatic changes. Voigt et al. (2006) showed that the Subhercynian Cretaceous Basin developed during frontal thrusting of a basement block of Harz and does not support the strike-slip model. Moreover, the observed changes in facies are explained by an interaction of eustasy and tectonics in that region (Voigt et al., 2006).

In the case of the Wielkanoc Block, we suggest that tectonic strike-slip activity has controlled sedimentation to a larger degree then did eustatic changes during the evolution of the Kraków Swell area in southern Poland.

\section{FINAL REMARK AND CONCLUSIONS}

1. The thickest succession of Coniacian age (ca. $1.5 \mathrm{~m}$ ), recognized in the Polish Jura Chain, is preserved in the Wielkanoc Quarry. These deposits represent only the upper Lower Coniacian Cremnoceramus crassus crassus/deformis deformis Zone.

2. On the Kraków Swell, which separated the Mid-Polish and Opole Troughs, at least locally (such as the Wielkanoc Block) calm and slow (mainly foraminiferal wackestone, coccolith sedimentary system, presence of dictyid sponges, glauconite) sedimentation occurred, interrupted by episodes of non-deposition (surfaces with burrows, episodes of phosphatization, intra-Coniacian discontinuity surfaces).

3. The large amount of planispiral and trochospiral planktonic foraminifers with globular chambers and the occurrence of siliceous sponges (Hexactinosida and Lychniscosida) in the Coniacian succession of Wielkanoc indicate water depths below storm base in the late Early Coniacian.

4. Tectonic activity of the Kraków Swell during the Turonian and Coniacian correspond well to the llsede Phase of Subhercynian tectonic movements. These tectonic movements were also responsible for strike-slip tectonic activity of the Kraków-Myszków Zone. As a result, sedimentation on the Kraków Swell was controlled by activity of the pre-Permian basement during the Turonian and Coniacian. The Wielkanoc area had a tendency to subside and created a local sub-basin through this time span.

Acknowledgements. The authors are greatly indebted to A. Świerczewska and K. Nejbert for help with the field work, to M. Babel and K. Nejbert for valuable comments, to B. Kołodziej, M. Wilmsen and an anonymous reviewer for critical valuable remarks, to T. Peryt for editorial screening, to P. Czubla for help in making photographs of the sponge specimens, to M. Wróbel for help with SEM images and to R. Macdonald for linguistic correction. The statutory fund of the Institute of Geology, University of Warsaw (BSt 163702) and statutory fund of the Laboratory of Geology, University of Lodz (project 560/844), have supported this research. 


\section{REFERENCES}

Alexandrowicz S. (1954) Turonian of the southern part of the Cracow Upland (in Polish with English summary). Acta Geologica Polonica, 4 (3): 361-390.

Alexandrowicz S. (1969) Les dépots transgressifs du Santonien aux environs de Cracovie (in Polish with French summary). Zeszyty Naukowe AGH, Geologia, 11: 45-59.

Barczyk W. (1956) On the Upper Chalk Deposits on Bonarka near Cracow (in Polish with English summary). Studia Societatis Scientiarum Toruniensis, 3 (2): 23-48.

Buła Z. (1994) Problemy stratygrafii i wykształcenia osadów starszego paleozoiku północno-wschodniego obrze enia Górnośląskiego Zagłębia Węglowego. Prace Naukowe Uniwersytetu Śląskiego, 1431: 31-57

Buła Z., aba J., Habryn R. (2008) Tectonic subdivision of Poland: southern Poland (Upper Silesian Block and Małopolska Block) (in Polish with English summary). Przegląd Geologiczny, 56 (10): 912-920.

Dadlez R. (1997) General tectonic framework of the Mid-Polish Trough (in Polish with English summary). Prace Państwowego Instytutu Geologicznego, 153: 410-414.

Defretin-Lefranc S. (1960) Contribution à l'étude des spongiaires siliceux du Crétacé supérieur du Nord de la France. Thèses a la Faculte des Sciences de Lille, (1958): 1-178.

Dubicka Z., Peryt D. (2012a) Foraminifers and stable isotope re cord of the Dubivtsi chalk (upper Turonian, Western Ukraine): palaeoenvironmental implications. Geological Quarterly, 56 (1): 199-214.

Dubicka Z., Peryt D. (2012b) Latest Campanian and Maastrichtian palaeoenvironmental changes: implications from an epicontinental sea (SE Poland and western Ukraine). Cretaceous $\mathrm{Re}$ search, 37: 272-284.

Finks R.M., Rigby J.K. (2004) Geographic and stratigraphic distribution. In: Treatise on Invertebrate Paleontology, Part E (Revised), Porifera 3. (ed. R. Kaesler): 275-296. The Geological Society of America and University of Kansas.

Hakenberg M., Świdrowska J. (1998) Evolution of the Holy Cross segment of the Mid-Polish Trough during the Cretaceous. Geological Quarterly, 42 (3): 239-262.

Hancock J.M. (1990) Sea-level changes in the British region during the Late Cretaceous. Proceedings of the Geologists' Association, 100 (4): 565-594.

Hancock J.M., Kauffman E.G. (1979) The great transgressions of the Late Cretaceous. Journal of the Geological Society of London, 136: 175-186.

Haq B.W., Hardenbol J., Vail P.R. (1988) Mesozoic and Cenozoic chronostratigraphy and cycles of sea-level changes. SEPM Special Publication, 42: 71-108.

Harding T.P. (1985) Seismic characteristic and identification of negative flower structures, positive flower structures, and positive structural inversion. AAPG Bulletin, 69 (4): 582-600.

Hogg M.M., Tendal O.S., Conway K.W., Pomponi S.A., Van Soest R.W.M., Gutt J., Krautter M., Roberts J.M. (2010) Deep-sea sponge grounds: reservoirs of biodiversity. UNEP-WCMC Biodiversity, Series, 32: 1-84.

Ijima I. (1927) The Hexactinellida of the Siboga Expedition. Siboga-Expeditie, 6: 1-383.

Janussen D., Tendal O.S. (2007) Diversity and distribution o Porifera in the bathyal and abyssal Weddell Sea and adjacent areas. Deep-Sea Research, part II, 54 (16-17): 1864-1875.

Jasionowski M. (1995) A Cretaceous non-depositional surface in the Kraków Upland (Mydlniki, Zabierzów), burrows, borings, stromatolites (in Polish with English summary). Annales Societatis Geologorum Poloniae, 65 (1-4): 63-77.

Jaskowiak-Schoeneichowa M., Krassowska A. (1988) Paleothickness, lithofacies and paleotectonics of the epicontinenta Upper Cretaceous in Poland (in Polish with English summary). Kwartalnik Geologiczny, 32 (1): 177-198.
Jurewicz E., Hercman H., Nejbert K. (2007) Flowstone-like calcite in the andesite of Jarmuta Mt. - dating the Holocene tectonic activity in the vicinity of Szczawnica (Magura Nappe, Outher Carpathians, Poland). Geologica Polonica, 57 (2): 187-204.

Kauffman E.G. (1973) Cretaceous Bivalvia. In: Atlas of Palaeobiogeography (ed. A.H. Hallam): 353-386. Elsevier, Amsterdam-London-New York.

Kaziuk H. (1978) Mapa geologiczna Polski 1:200000, ark. Kraków B Mapa bez utworów czwartorzędowych. Wydawnictwa Geologiczne, Warszawa.

Kołodziej B., Szulc J., Machaniec E., Kędzierski M., Duda M. (2010) Injection dykes as evidence of Campanian synsedimentary tectonics on the Kraków Swell, southern Poland. Annales Societatis Geologorum Poloniae, 80 (3): 285-301.

Krajewski K.P., Leśniak P.M., Łącka B., Zawidzki P. (2000) Origin of phosphatic stromatolites in the Upper Cretaceous condensed sequence of the Polish Jura Chain. Sedimentary Geology, 136 (1): 89-112.

Krautter M. (1997) Aspekte zur Paläökologie postpaläozoischer Kieselschwämme. Profil, 11: 199-324.

Krautter M., Conway K.W., Barrie J.V. (2006) Recent hexactinosidian sponge reefs (silicate mounds) off British Columbia, Canada: Frame-building processes. Journal of Paleontology, 80: $38-48$

Kudrewicz R., Olszewska-Nejbert D. (1997) Upper Cretaceous "Echinoidlagerstätten" in the Kraków area. Annales Societatis Geologorum Poloniae, 67 (1): 1-12.

Leckie R.M. (1987) Paleoecology of mid-Cretaceous planktonic foraminifera: a comparison of open ocean and epicontinental sea assemblages. Micropaleontology, 33: 164-176.

Leszczyński K. (1997) The Upper Cretaceous carbonate-dominated sequences of the Polish Lowlands. Geological Quarterly, 41 (4): 521-532.

Leszczyński K. (2002) The Cretaceous evolution of the Ponętów-Wartkowice Zone (in Polish with English summary). Prace Państwowego Instytutu Geologicznego, 176: 1-96.

Leszczyński K. (2012) The internal geometry and lithofacies pattern of the Upper Cretaceous-Danian sequence in the Polish Lowlands. Geological Quarterly, 56 (2): 363-386.

Leszczyński S. (2010) Coniacian-?Santonian paralic sedimentation in the Rakowice Małe area of the North Sudetic Basin, SW Poland: sedimentary facies, ichnological record and palaeogeographical reconstruction of an evolving marine embayment. Annales Societatis Geologorum Poloniae, 80 (1): 1-24.

Leys S.P., Wilson K., Holeton C., Reiswig H.M., Austin W.C., Tunniclif V. (2004) Patterns of glass sponge (Porifera, Hexactinellida) distribution in coastal waters of British Columbia, Canada. Marine Ecology Progress Series, 283: 133-149.

Marcinowski R. (1974) The transgressive Cretaceous (Upper Albian through Turonian) deposits on the Polish Jura Chain. Acta Geologica Polonica, 24 (1): 117-217.

Marcinowski R., Radwański A. (1983) The Mid-Cretaceous transgression onto the Central Polish Uplands (marginal part of the Central European Basin). Zitteliana, 10: 65-95.

Marcinowski R., Radwański A. (2009) A unique habitat of endolithic biota: Seism-included limestone rubble in Albian sandmass of the Cracow Upland, southern Poland. Acta Geologica Polonica, 59 (4), 505-521.

Matyszkiewicz J., Krajewski M., aba J. (2006) Structural control on the distribution of Upper Jurassic carbonate buildups in the Kraków-Wieluń Upland (south Poland). Neues Jahrbuch für Geologie und Paläontologie Monatshefte, 2006 (3): 182-192.

Mehl D., Niebuhr B. (1995) Diversität und Wachstumsformen bei Coeloptychium (Hexactinellida, Lychniskosa) der Meiner Mulde (Untercampan, N-Deutschland) und die Palökologie der Coeloptychidae. Berliner Geowissenschaftliche Abhandlungen, E16: 91-107. 
Mortimore R.N. (2011) A chalk revolution: what have we done to the Chalk of England? Proceedings of the Geologists' Association, 122 (2): 232-297.

Mortimore R., Pomerol B. (1997) Upper Cretaceous tectonic phases and end Cretaceous inversion in the Chalk of the Anglo-Paris Basin. Proceedings of the Geologists' Association, 108: 231-255.

Mortimore R., Wood C., Pomerol B., Ernst G. (1998) Dating the phases of the Subhercynian tectonic epoch: Late Cretaceous tectonics and eustatics in the Cretaceous basins of northern Germany compared with the Anglo-Paris Basin. Zentralblatt fü Geologie und Paläontologie, Teil 1, 1996, (11/12): 1349-1401.

Naidin D.P. (1959) On the paleogeography of Russian Platform during the Upper Cretaceous epoch. Stockholm Contributions in Geology, 3: 127-138

Nestler H. (1961) Spongien aus der weissen Schreibkreide (unt Maastricht) der Insel Rügen (Ostsee). Paläontologische Abhandlungen, 1: 1-70.

Niebuhr B. and Prokoph A. (1997) Periodic-cyclic and chaotic successions of Upper Cretaceous (Cenomanian to Campanian) pelagic sediments in the North German Basin. Cretaceous Research, 18 (5): 731-750.

Niebuhr B., Baldschuhn R., Ernst G., Walaszczyk I., Weiss W. Wood C.J. (1999) The Upper Cretaceous succession (Cenomanian-Santonian) of the Staffhorst Shaft, Lower Saxony, northern Germany: intergrated biostratigraphic, lithostratigraphic and downhole geophysical log data. Acta Geologica Polonica, 49 (3): 175-213.

Niebuhr B., Wilmsen M., Chellouche P., Richardt N., Pürner T. (2011) Stratigraphy and facies of the Turonian (Upper Cretaceous) Roding Formation at the southwestern margin of the Bohemian Massif (southern Germany, Bavaria). Zeitschrift der Deutschen Gesellschaft für Geowissenschaften, 62 (3): 295-316.

Olszewska-Nejbert D. (2004) Development of the Turonian/Coniacian hardground boundary in the Cracow Swell area (Wielkanoc quarry, Southern Poland). Geological Quarterly, 48 (2): 159-168.

Olszewska-Nejbert D. (2005) Development of the Turonian Conulus Lagerstätte in the Wielkanoc Quarry (South Poland). Annales Societatis Geologorum Poloniae, 75 (3): 199-210.

Olszewska-Nejbert D. (2007) Late Cretaceous (Turonian-Coniacian) irregular echinoids of western Kazakhstan (Mangyshlak) and southern Poland (Opole). Acta Geologica Polonica, 57 (1) $1-87$.

Olszewska-Nejbert D., Świerczewska-Gładysz E. (2009) The phosphatized sponges from the Santonian (Upper Cretaceous) of the Wielkanoc Quarry southern Poland) as a tool in stratigraphical and environmental studies. Acta Geologica Polonica, 59 (4): 483-504.

Olszewska-Nejbert D., Świerczewska-Gładysz E. (2011) Campanian (Late Cretaceous) hexactinellid sponges from the white chalk of Mielnik (Eastern Poland). Acta Geologica Polonica, 61 (4): 383-417.

Panow E. (1934) - Sur la stratigraphie du crétacé des environs de Cracovie note préliminaire (in Polish with French summary) Annales Societatis Geologorum Poloniae, 10: 577-585.

Pisera A. (1999) Postpaleozoic history of the siliceous sponges with rigid skeleton. Memoirs of the Queensland Museum, 44: 463-472.

Radwańska Z. (1969) Kreda w otworze Sady IG 1. Kwartalnik Geologiczny, 13 (3): 709-710.

Reid R.E.H. (1962) Relationships of fauna and substratum in the paleoecology of the Chalk and Chalk Rock. Nature, 194: (4825): 276-277.

Reid R.E.H. (1968) Hexactinellid faunas in the Chalk of England and Ireland. Geological Magazine, 105 (1): 15-22

Reiswig H.M. (2002) Order Lychniscosida Schrammen, 1903. In: Systema Porifera: a Guide to the Classification of Sponges (eds. J.N.A. Hooper and van R.W.M. Soest): 1377-1385. Kluwer Academic/Plenum, Amsterdam.
Reiswig H.M., Wheeler B. (2002) Family Euretidae Zittel, 1877. In: Systema Porifera: a Guide to the Classification of Sponges (eds. J.N.A. Hooper and van R.W.M. Soest): 1301-1331. Kluwer Academic/Plenum, Amsterdam.

Richardt N., Wilmsen M. (2012) Lower Upper Cretaceous standard section of the southern Münsterland (NW-Germany): carbon stable isotopes and sequence stratigraphy. Newsletters on Stratigraphy, 45: 1-24.

Różycki S.Z. (1938) Stratigraphie und Tektonik der Kreideablagerungen der umgebung von Lelów (Südöstlisch von Częstochowa) (in Polish with German summary). Sprawozdania Państwowego Instytutu Geologicznego, 9 (2): 127-176.

Schneider S., Niebuhr B., Wilmsen M., Vodrážka R. (2011) Between the Alb and the Alps - the fauna of the Upper Cretaceous Sandbach Formation (Passau region, southeast Germany). Bulletin of Geosciences, 86 (4): 785-816.

Smoleński J. (1906) Lower Senonian at Bonarka; 1. Cephalopods and Inoceramids (in Polish). Rozprawy Wydziału Matematyczno-Przyrodniczego Akademii Umiejętności, Kraków, Seria B, 46: 1-34.

Sujkowski Z. (1926) Sur le Jurassique, le Crétacé et le Quaternaire des environs de Wolbrom (in Polish with French summary). Sprawozdania Państwowego Instytutu Geologicznego, 3 (3-4): 382-434.

Sujkowski Z. (1934) Roches crétacées entre les villes Pilica et Szczekociny (in Polish with French summary). Sprawozdania Państwowego Instytutu Geologicznego, 8 (1): 39-75.

Świdrowska J., Hakenberg M. (1999) Subsidence and the problem of incipient inversion in the Mid-Polish Trough based on thickness maps and Cretaceous lithofacies analysis (in Polish with English summary). Przegląd Geologiczny, 47 (1): 61-68.

Świerczewska-Gładysz E. (2006) Late Cretaceous siliceous sponges from the Middle Vistula River Valley (Central Poland) and their palaeoecological significance. Annales Societatis Geologorum Poloniae, 76 (3): 227-296.

Świerczewska-Gładysz E. (2010) Late Hexactinellid sponges from the Santonian deposits of the Kraków area (southern Poland). Annales Societatis Geologorum Poloniae, 80 (3): 253-284.

Tabachnick K.R. (1991) Adaptation of the Hexactinellid sponges to deep-sea. In: Fossil and Recent Sponges (eds J. Reitner and H. Keupp): 378-386. Springer Verlag, Berlin.

Tarkowski R. (1991) Stratigraphy, macrofossils and palaeogeography of the Upper Cretaceous from the Opole Trough (in Polish with English summary). Zeszyty Naukowe AGH, Geologia, $\mathbf{5 1}$ $1-156$

Tröger K.A. (1995) Die Subhercyne Oberkreide - Beziehungenzum Variscischen Grundgebirge und Stellung innerhalb Europas. Nova Acta Leopoldina, NF 71, 291: 217-231.

Ulbrich H. (1974) Die Spongien der Ilsenburg-Entwicklung (Oberes Unter-Campan) der Subherzynen Kreidemulde. Freiberger Forschungshefte, C291: 1-121.

Uličný D., Čech S., Grygar R. (2003) Tectonics and depositional systems of a shallow-marine, intra-continental strike-slip basin: exposures of the Český Ráj Region, Bohemian Cretaceous Basin. GeoLines, 16: 133-148.

Van Soest R.W.M., van Stentoft N. (1988) Barbados Deep-Water Sponges. In: Studies on the Fauna of Curaçao and other Caribbean Islands (eds. P.W. Hummelinck and van der L.J. Steen), Utrecht, Foundation for Scientific Research in Surinam and the Netherlands Antiles, 70 (215): 1-175.

Voigt T., von Eynatten H., Franzke H.J. (2004) Late Cretaceous unconformities in the Subhercynian Cretaceous Basin (Germany). Acta Geologica Polonica, 54 (4): 673-694.

Voigt T., Wiese F., von Eynatten H., Franzke H.-J., Gaupp R (2006) Facies evolution of syntectonic Upper Cretaceous deposits in the Subhercynian Cretaceous Basin and adjoining areas (Germany). Zeitschrift der Deutschen Gesellschaft für Geowissenschaften, 157 (2): 203-244.

Wagner W. (1963) Die Schwammfauna der Oberkreide von Neuburg (Donau). Palaeontographica, Abteilung A, 122: 166-250. 
Wagner W. (1963) Die Schwammfauna der Oberkreide von Neuburg (Donau). Palaeontographica, Abteilung A, 122: 166-250.

Walaszczyk I. (1992) Turonian through Santonian deposits of the Central Polish Uplands; their facies development, inoceramid paleontology and stratigraphy. Acta Geologica Polonica, 42 (1-2): 1-122.

Walaszczyk I. (2000) Inoceramid bivalves at the Turonian/Coniacian boundary: biostratigraphy, events, and diversity trends. Acta Geologica Polonica, 50 (4): 421-430.

Walaszczyk I., Wood C.J. (1998) Inoceramid and biostratigraphy at the Turonian/Coniacian boundary; based on the SalzgitterSalder Quarry, Lower Saxony, Germany, and the Słupia Nadbrze na section, Central Poland. Acta Geologica Polonica, 48 (4): 395-434.

Walaszczyk I., Wood C.J., Lees J.A., Peryt D., Voigt S., Wiese F. (2010) The Salzgitter-Salder Quarry (Lower Saxony, Germany) and Słupia Nadbrze na river cliff section (central Poland): a proposed candidate composite Global Boundary Stratotype Section and Point for the Coniacian Stage (Upper Cretaceous). Acta Geologica Polonica, 60 (4): 445-477.

Whitney F., Conway K.W., Thomson R.E., Barrie J.V., Krautter M., Mungov G. (2005) Oceanographic habitat of sponge reefs on the Western Canadian Continental Shelf. Continental Shelf Research, 25: 211-226.

Wiese F. (2009) The Söhlde Formation (Cenomanian, Turonian) of NW Germany: Shallow marine pelagic red beds. SEPM Special Publication, 91: 153-170.

Wiese F., Čech S., Ekrt B., Košt’ák M., Mazuch M., Voigt S. (2004) The Upper Turonian of the Bohemian Cretaceous Basin (Czech Republic) exemplified by the Úpohlavy working quarry: inte- grated stratigraphy and palaeoceanography of a gateway to the Tethys. Cretaceous Research, 25: 329-352.

Wilmsen M. (2003) Sequence stratigraphy and palaeoceanography of the Cenomanian Stage in northern Germany. Cretaceous Research, 24 (5): 525-568.

Wood C.J., Ernst G., Rasemann G. (1984) The Turonian-Coniacian stage boundary in Lower Saxony (Germany) and adjacent areas: the Salzgitter-Salder Quarry as a proposed international standard section. Bulletin of the Geological Society of Denmark, 33 (1-2): 225-238.

Zapałowicz-Bilan B., Pilarz M., Machaniec E. (2009) Micropalaeontology biostratigraphy of the Upper Cretaceous and Miocene deposits in "Bibice" borehole (Kraków area) (in Polish with English summary). Geologia (Kwartalnik AGH), 35 (2/1): 95-103.

Zaręczny S. (1878) O średnich warstwach kredowych w Krakowskim okręgu. Sprawozdania Komisji Fizjograficznej Akademii Umiejętności, 12: 176-246.

Ziegler P.A. (1990) Geological Atlas of Western and Central Europe (2nd ed.). Shell Internationale Petroleum Maatschappij B.V.; Mijdrecht, The Hague, Amsterdam.

aba J. (1996) Late Carboniferous strike slip activity at the boundary zone of Upper Silesia and Małopolska Blocks (in Polish with English summary). Przegląd Geologiczny, 44 (2): 173-180.

aba J. (1999) The structural evolution of Lower Palaeozoic succession in the Upper Silesia Block and Małopolska Block border zone (southern Poland) (in Polish with English summary). Prace Państwowego Instytutu Geologicznego, 166: 1-162.

Žitt J., Vodražka R., Hradecka L., Svobodova M., Zagoršek K. (2006) Late Cretaceous environments and communities recorded at Chrtniky (Bohemian Cretaceous Basin, Czech Republic). Bulletin of Geosciences, 81 (1): 43-79. 